\title{
PENGARUH BUDAYA KERJA, LINGKUNGAN KERJA, KOMPENSASI FINANSIAL, DAN KOMPENSASI NON FINANSIAL TERHADAP KINERJA KARYAWAN TETAP PT. SURABAYA PANEL LESTARI GRESIK
}

\section{Siti Aizah}

Program Studi Manajemen Fakultas Ekonomi dan Bisnis

Universitas Muhammadiyah Gresik

\begin{abstract}
This research aims to test the influence of the culture of the Organization, the work environment, Financial Compensation, and Non financial Compensationperformance against permanent employees of PT. Surabaya Panel Lestari Gresik. Then conducted a review of the literature and the preparation of the hypothesis, as well as the data obtained from the dissemination of questionnaires against 62 permanent employees of PT. Surabaya Panel Lestari Gresik using Total Sampling. Testing is done using multiple Linear regression analysis. The results of the analysis show that organizational culture does not have an effect on the variable performance of the employees, the influential working environment significantly to the performance of the employee, financial compensation is a significant effect on performance of employees and Non financial compensation effect significantly to the performance of the employee. The culture of the Organization, the work environment, Financial Compensation, Non financial Compensationsignificant effect simultaneously against variable employee performance.
\end{abstract}

Keywords: culture, environment, Compensation, performance.

\section{PENDAHULUAN}

Pada era globalisasi seperti sekarang ini, kualitas dipandang sebagai suatu alat untuk mencapai keunggulan yang kompetitif. Perusahaan lokal di suatu negara harus menghadapi perusahaan lain yang memiliki keunggulan yang lebih kompetitif. Situasi seperti ini membuat perusahaan harus mampu menyesuaikan diri dan bertahan. Salah satu strategi yang tepat adalah dengan meningkatkan kualitas sumber daya manusia, karena sumber daya manusia yang dimiliki organisasi merupakan aset penting yang dapat memberikan keunggulan bersaing bagi organisasi.

Karyawan dalam sebuah perusahaan merupakan sumber daya yang sangat menentukan tercapainya tujuan perusahaan. Pencapaian tujuan perusahaan bukanlah hal yang mudah dilakukan karena diperlukan strategi untuk mencapainya. Masalah mendasar yang sering dihadapi perusahaan adalah bagaimana mengelola sumber daya manusia untuk melakukan tugas dengan sebaikbaiknya dalam rangka mencapai tujuan yang telah ditetapkan. Setiap perusahaan ingin karyawannya memiliki kinerja yang tinggi dalam bekerja. Kinerja yang tinggi dari sumber daya manusia sebuah organisasi dapat menjadi keunggulan kompetitif dari organisasi itu sendiri karena tidak mudah ditiru pesaingnya.

PT. Surabaya Panel Lestari merupakan salah satu perusahaan yang bergerak di bidang pembuatan furniture yang berlokasi di Jl. Kapten 
Darmosugondo Ds. Karang Kering, Kebomas, Gresik dan merupakan anak cabang dari Olympic Group yang berpusat di Bogor. Sebagai produsen furniture ternama, Olympic telah berkiprah selama 26 tahun dan mempunyai lebih dari 70 cabang diseluruh Indonesia yang pendistribusian produk-produknya ke 3600 toko di lebih dari 100 negara seluruh pelosok dunia. Hingga saat ini perusahaan tetap eksis dalam mempertahankan citra perusahaan dan terus aktif melakukan penetrasi pasar melalui berbagai macam cara dan diskon bagi toko dan konsumen.

PT. Surabaya Panel Lestari adalah salah satu dari sekian banyak anak cabang dari Olympic Group yang konsisten memproduksi tipe-tipe seperti produk almari, meja rias, meja belajar, meja kantor dan lain-lain. Saat ini produk-produk Olympic banyak diminati pasar karena selain harga yang kompetitif juga corak dan bentuk serta variasi yang ada telah mampu menarik minat banyak orang untuk memilikinya serta didukung juga dengan jaringan layanan purna jual seluruh Indonesia. Mengingat pentingnya permintaan konsumen saat ini, maka PT. Surabaya Panel Lestari lebih aktif dalam pemasaran dan mendistribusikan produk sejenis dengan merk-merk yang lebih variatif seperti Albatros, Solid, Princess, Olympic, Innovative yang telah mendapatkan beberapa macam penghargaan dan pengakuan baik di dalam maupun di luar negeri.

Salah satu perusahaan yang menerapkan penilaian kinerja adalah PT. Surabaya Panel Lestari. Selama ini penilaian kinerja pada perusahaan ini dilakukan secara langsung oleh atasan dari masing-masing karyawan (seperti supervisor, manajer, kepala satuan organisasi, dan direksi) dan departemen sumber daya manusia (SDM) sebagai pihak yang bertanggung jawab pada presensi karyawan. Melihat proses penilaian kinerja yang cukup birokratif dengan banyaknya divisi dan cabang tentunya sering terjadi kendala dalam proses ini, seperti terjadinya keterlambatan tiap divisi dalam melakukan penilaian kinerja yang disebabkan oleh kesibukan para pimpinan bagian produksi, kesulitan dari pihak SDM dalam melakukan penilaian kinerja karyawan dari tiap divisi dan bagian, serta kesulitan dalam melakukan record hasil penilaian kinerja ditiap periode yang ada. Hal ini tentunya memperlambat kerja pihak SDM dalam membuat rekapan kinerja karyawan setiap tahunnya baik di wilayah perusahaan pusat maupun perusahaan cabang. Fenomena menarik di lapangan terjadi penurunan kinerja dari PT. Surabaya Panel Lestari oleh para karyawannya di bagian produksi.

\section{TINJAUAN PUSTAKA}

Penelitian yang dilakukan oleh Gogy Bara Kharisma. 2013 "Pengaruh Budaya Organisasi Dan Lingkungan Kerja Terhadap Kinerja Karyawan Koperasi Serba Usaha Setya Usaha Di Kabupaten Jepara" yang dikaji dari penelitian ini adalah bagai mana gambaran Budaya Organisasi, Lingkungan Kerja dan Kinerja Kayawan pada Koperasi Serba Usaha Setya Usaha di Kabupaten Jepara. Penelitian ini bertujuan untuk mengetahui dan mendeskripsikan pengaruh budaya Organisasi dan Lingkungan Kerja terhadap Kinerja Karyawan Koperasi Serba Usaha Setya Usaha, baik secara simltan ataupun parsial. Teknik pengamilan sampel dalam penelitian ini dengan menggunakan teknik populasi studi 
sensus, sehingga seluruh populasi dijadikan sebagai sampel. Metode pengumpulan data yang di gunakan adalah metode kuesioner. Teknik analisis digunakan dalam penelitian ini adalah regresi berganda

\section{Kinerja}

Kinerja menurut Rivai (2009 ; 14) menyatakan bahwa kinerja adalah hasil atau tingkat keberhasilan seseorang secara keseluruhan selama periode tertentu dalam melaksanakan tugas dibandingkan dengan berbagai kemungkinan, seperti standar hasil kerja, target atau sasaran atau kriteria yang telah ditentukan terlebih dahulu dan telah disepakati bersama.

Menurut Prawirosentono dikutip oleh Usman (2009: 488), kinerja atau performance adalah usaha yang dilakukan dari hasil kerja yang dapat dicapai oleh seseorang atau sekelompok orang dalam suatu organisasi sesuai dengan wewenang dan tanggung jawab masing-masing dalam rangka mencapai tujuan organisasi bersangkutan secara legal, tidak melanggar hukum. Menurut Mangkunegara (2008:67), kinerja adalah hasil kerja secara kualitas dan kuantitas yang dicapai oleh seorang karyawan dalam melaksanakan tugasnya sesuai dengan tanggung jawab yang diberikan padanya.

\section{Budaya Organisasi}

Deal dan kennedi (2007:56) mengemukakan bahwa ciri-ciri organisasi yang memiliki budaya organisasi kuat sebagai berikut :

1. Anggota-anggota organisasi loyal kepada organisasi, tahu dan jelas apa tujuan organisasi serta mengerti perilaku mana yang dipandang baik dan tidak baik.

2. Pedoman bertingkah laku bagi orang-orang di dalam instansi digariskan dengan jelas, dimengerti, dipatuhi dan dilaksanakan oleh orang-orang di dalam instansi sehingga orangorang yang bekerja menjadi sangat kohesif.

3. Nilai-nilai yang dianut organisasi tidak hanya berhenti pada slogan, tetapi dihayati dan dinyatakan dalam tingkah laku sehari-hari secara konsisten oleh seluruh SDM, dari yang berpangkat rendah hingga pimpinan tertinggi.

4. Organisasi/ instansi memberikan tempat khusus kepada pahlawanpahlawan instansi dan secara sistematis menciptakan berbagai tingkat pahlawan, misalnya, pemberi saran terbaik, inovator tahun ini, dan sebagainya

5. Memiliki jaringan kulturul yang menampung cerita-cerita kehebatan para pahlawannya. Budaya organisasi yang kuat menjadi mekanisme control dan menjadi rasional yang memandu dan membentuk sikap serta perilaku para karyawan sehingga sangat mempengaruhi kinerja.

\section{Lingkungan Kerja}

Lingkungan kerja menurut Nitisemito, oleh penelitian Nasution dan Rodhiah dalam (Jurnal Manajemen, 2008:58) adalah segala sesuatu yang ada disekitar pekerjaan yang dapat mempengaruhi dirinya dalam menjalankan tugas-tugas yang dibebankan. Sementara itu, menurut Fieldman oleh penelitian Nasution dan Rodhiah (2008:58) menjelaskan bahwa lingkungan kerja merupakan faktor-faktor diluar manusia baik fisik maupun non fisik dalam suatu organisasi yang pembentukannya terkait dengan kemampuan manusia. Berdasarkan definisi diatas, maka dapat disimpulkan bahwa lingkungan 
kerja adalah sebuah hal yang berada disekitar pekerjaan mempengaruhi karyawan dalam melaksanakan tugas, kondisi kerja, hubungan karyawan di dalam perusahaan dan kinerja karyawan tersebut. Robbins (2009:57) menyatakan bahwa "faktor-faktor mempengaruhi lingkungan kerja fisik adalah: suhu, kebisingan, penerangan, dan mutu udara.

\section{Kompensasi Finansial}

Hakikatny manusia bekerja juga ingin memperoleh uang untuk memenuhi kebutuhan hidupnya. Untuk itulah seorang karyawan mulai menghargai kerja keras dan semakin menunjukkan loyalitas terhadap perusahaan dan karena itulah perusahaan memberikan penghargaan terhadap prestasi kerja karyawan dengan jalan memberikan kompensasi. Kompensasi merupakan sesuatu yang diterima karyawan sebagai pengganti kontribusi mereka pada perusahaan. Pemberian kompensasi merupakan salah satu pelaksanaan fungsi MSDM berhubungan dengan semua jenis pemberian penghargaan individual sebagai pertukaran dalam melakukan tugas organisasi Rivai (2008:357).

\section{Kompensasi Non Finansial}

Menurut Simamora (2014:30)

Kompensasi Non Finansial adalah segala bentuk penghargaan yang diberikan oleh perusahaan dalam bentuk bukan finansial atau bukan uang. Kompensasi Non Finansial meliputi tempat kerja yang nyaman dan Pekerjaan

\section{Hubungan Antar Variable}

\section{Hubungan Budaya Organisasi Dengan Kinerja Karyawan}

Robbins (2009:56) menyatakan bahwa budaya organisasi diukur dengan beberapa faktor yaitu profesionalisme kerja, jarak dari manajemen, sikap terbuka karyawan, keteraturan karyawan dan integrasi karyawan. Hasibuan (2010:98) mengatakan bahwa budaya yang kuat dapat menghasilkan efek yang sangat mempengaruhi individu dan kinerja, bahkan dalam suatu lingkungan bersaing pengaruh tersebut dapat lebih besar dari pada faktor-faktor lain seperti struktur organisasi, alat analisis keuangan, kepemimpinan dan lainnya.

\section{Hubungan Lingkungan Kerja} Dengan Kinerja Karyawan

Hubungan antara lingkungan kerja terhadap kinerja karyawan juga telah dibuktikan oleh Gibson (2009:110) Lingkungan kerja yang baik akan sangat besar pengaruhnya terhadap kinerja karyawan, aspek yang berpengaruh terhadap lingkungan kerja antara lain: pengaturan penerangan, tingkat kerja, namun penerangan di sini diartikan sebagai pengaturan dan sirkulasi udara yang baik terutama di dalam lingkungan kerja, kebersihan lingkungan kerja.

Hubungan Kompensasi Finansial Dengan Kinerja Karyawan

Hasibuan (2008:117) mengemukakan bahwa: Besarnya balas jasa ditentukan dan diketahui sebelumnya, sehingga karyawan secara pasti mengetahui besarnya balas jasa/ kompensasi yang akan diterimanya. Apabila kompensasi yang diterima karyawan berupa kompensasi finansial semakin besar maka kinerja karyawan semakin tinggi, sebaliknya apabila kompensasi yang diterima karyawan kompensasi finansial semakin rendah, maka kinerja karyawan juga rendah.

\section{Hubungan Kompensasi Non Finansial Dengan Kinerja Karyawan}

Menurut Mondy (2008:5) kompensasi non finansial adalah kepuasan yang diterima seseorang dari pekerjaan itu 
sendiri atau dari lingkungan psikologis dan fisik tempat orang tersebut bekerja. Adanya sistem kompensasi yang baik pada suatu organisasi diharapkan dapat meningkatkan kinerja karyawan. Apabila karyawan merasa kompensasi non finansialnya kurang sesuai dengan apa yang telah ia berikan, maka karyawan cenderung enggan berusaha untuk meningkatkan kinerjanya.

Hubungan Budaya Organisasi, Lingkungan Kerja, Kompensasi Finansial dan Kompensasi Non Finansial Dengan Kinerja Karyawan

Menurut Harpitasari (2010: 12) bahwa kinerja karyawan dipengaruhi oleh gaji, lingkungan kerja, budaya organisasi, kepemimpinan dan motivasi kerja (motivation), disiplin kerja, kepuasan kerja, motivasi. Ketika semua faktor tersebut tercapai dengan baik maka keinginan perusahaan untuk mencapai tujuan perusahan akan terlaksana.

\section{Kerangka Konseptual}

Kerangka pemikiran merupakan penjelasan sementara terhadap gejalagejala yang menjadi objek permasalahan, dengan budaya organisasi (X1) lingkungan kerja (X2) kompensasi finansial (X3) dan kompensasi non finansial (X4) merupakan variabel bebas (independent variabel), sedangakan kinerja karyawan (Y) merupakan variabel terikat (dependent variabel). pada penelitian ini akan menguji atau mencari adanya pengaruh signifikan antara variabel bebas dengan variabel terikat.

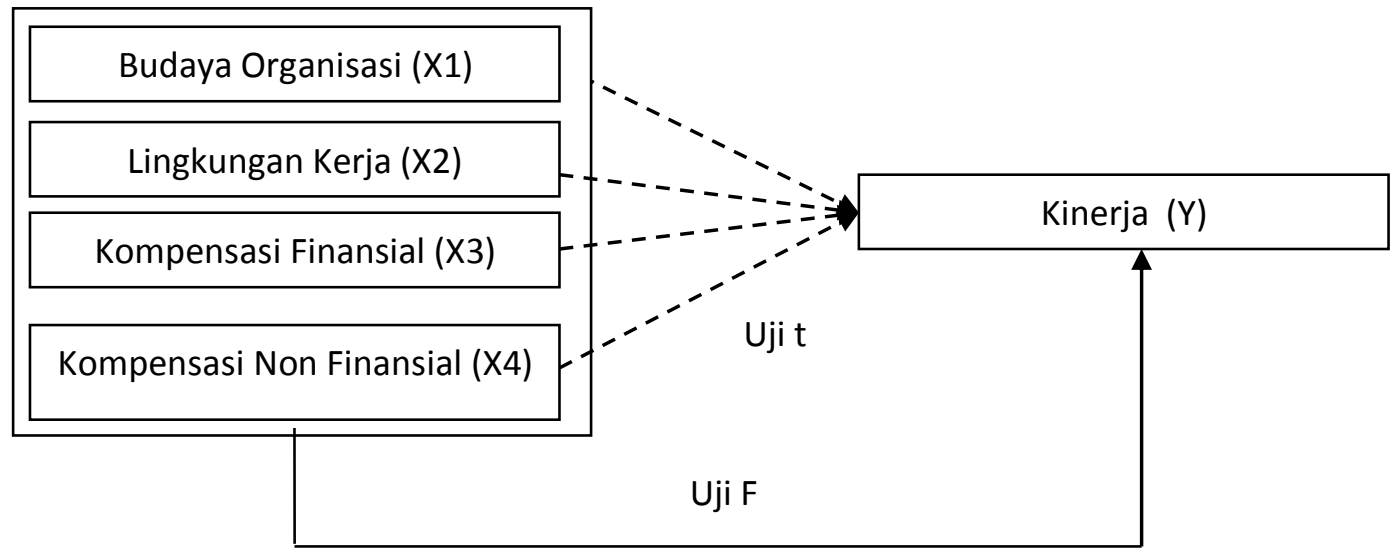

Keterangan :

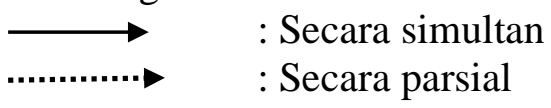

\section{Hipotesis}

Berdasarkan latar belakang dan permasalahan yang ada diarahkan untuk merujuk pada dugaan sementara, yaitu:

1. Diduga budaya organisasi berpengaruh terhadap karyawan PT. Surabaya Panel Lestari Gresik.

2. Diduga lingkungan kerja berpengaruh terhadap karyawan PT. Surabaya Panel Lestari Gresik.
3. Diduga kompensasi finansial berpengaruh terhadap karyawan PT. Surabaya Panel Lestari Gresik.

4. Diduga kompensasi non finansial berpengaruh terhadap karyawan PT. Surabaya Panel Lestari Gresik.

5. Diduga budaya organisasi berpengaruh terhadap karyawan PT. Surabaya Panel Lestari Gresik. 


\section{METODOLOGI PENELITIAN}

Penelitian ini menggunakan pendekatan kuantitatif. Penelitian ini dilakukan pada karyawan PT. Surabaya Panel Lestari Gresik. Adapun populasi dalam penelitian ini adalah Seluruh Karyawan tetap PT. Surabaya Panel Lestari dengan jumlah 62 karyawan.

Ada 5 variabel dalam penelitian ini, variable bebas adalah Budaya Organisasi (X1) Lingkung Kerja (X2), Kompensasi Finansial (X3), Kompensasi Non Finansial (X4) sedangkan variable terikat adalah Kinerja (Y).

Definisi operasional variable dalam penelitian ini sebagai berikut : budaya organisasi adalah misi, konsistensi, adaptibiltas, dan pelibatan. Lingkungan kerja: penerangan, ruang gerak dan hubungan karyawan bersinergi. Kompensasi Finansial : gaji UMK, insentif bonus dan tunjangan kesejahteraan. Kompensasi Non Finansial : pekerjaan yang sesuai dan tempat kerja yang nyaman. Pada penelitian ini teknik analisis data menggunakan pengujian hipotesis dengan menggunakan uji statistik, yaitu melalui analisis regresi linier berganda.

\section{HASIL PENELITIAN}

\section{Gambaran Perusahaan}

PT. Surabaya Panel Lestari merupakan salah satu perusahaan yang bergerak di bidang pembuatan furniture yang berlokasi di Jl. Kapten Darmosugondo Ds. Karang Kering, Kebomas, Gresik dan merupakan anak cabang dari Olympic Group yang berpusat di Bogor. Sebagai produsen furniture ternama,Olympic telah berkiprah selama 26 tahun dan mempunyai lebih dari 70 cabang diseluruh Indonesia yang pendistribusian produk- produknya ke 3600 toko di lebih dari 100 negara seluruh pelosok dunia. Hingga saat ini perusahaan tetap eksis dalam mempertahankan citra perusahaan dan terus aktif melakukan penetrasipasar melalui berbagai macam cara dan diskon bagi toko dan konsumen.

PT. Surabaya Panel Lestari adalah salah satu dari sekian banyak anak cabang dari Olympic Group yang konsisten memproduksi tipe-tipe seperti produk almari, meja rias, meja belajar, meja kantor dan lain-lain. Saat ini produk-produk Olympic banyak diminati pasar karena selain harga yang kompetitif juga corak dan bentuk serta variasi yang ada telah mampu menarik minat banyak orang untuk memilikinya serta didukung juga dengan jaringan layanan purna jual yang luas di seluruh Indonesia. Mengingat pentingnya permintaan konsumen saat ini,maka PT. Surabaya Panel Lestari lebih aktif dalam pemasaran dan mendistribusikan produk-produk sejenis dengan merkmerk yang lebih variatif seperti Albatros, Solid, Princess, Olympic, Innovative yang telah mendapatkan beberapa macam penghargaan dan pengakuan baik di dalam maupun di luar negeri.

\section{Gambaran Umum Responden}

Sebagaimana dijelaskan sebelumnya bahwa responden adalah penelitian ini adalah karyawan tetap PT. Surabaya Panel Lestari. Dalam penelitian ini disediakan 70 kuesioner, di mana pengisian kuesioner dengan pendekatan pemberian penjelasan dan panduan kepada responden terdapat 8 kuesioner yang tidak diisi lengkap, sisanya sebanyak 62 kuesioner memenuhi kualifikasi untuk penelitian. 
Dari seluruh jumlah kuesioner, diperoleh 62 kuesioner yang digunakan untuk analisis data. Semua informasi mengenai hasil penelitian dan informasi responden tersebut diperoleh dari hasil distribusi kuesioner yang diperoleh kembali. Dari kuesioner yang diisi responden didapat data identitas responden. Penyajian data mengenai identitas responden memberikan gambaran tentang keadaan diri dari responden.

\section{Interpretasi Hasil}

Penelitian ini bertujuan untuk melihat apakah Budaya organisasi, lingkungan kerja, kompensasi finansial dan kompensasi non finansial berpengaruh signifikan secara parsial terhadap kinerja karyawan PT. Surabaya Panel Lestari Gresik. Berdasarkan penelitian dan analisis yang peneliti lakukan dengan menggunakan alat bantu SPSS 17, maka peneliti dapat menginterpretasikan hasil berikut dalam pengujian hipotesis secara parsial dengan menunjukkan uji $t$ antara masing-masing variabel independen dan variabel dependen diperoleh hasil Budaya organisasi tidak berpengaruh terhadap kinerja karyawan karena t hitung lebih kecil daripada $t$ tabel dengan demikian hipotesis satu tidak terbukti kebenaranya. dan untuk varibael yang lainya yaitu lingkungan kerja, kompensasi finansial dan kompensasi non finansial berpengaruh signifikan terhadap kinerja karyawan, dengan demikian hipotesis dua, tiga dan empat terbukti kebenaranya.

\section{Budaya Organisasi (X1) terhadap kinerja (Y)}

Untuk melihat pengaruh parsial antara budaya organisasi terhadap kinerja karyawan, peneliti menggunakan tahap berupa penetapan hipotesis, pengolahan data kuantitatif dengan SPSS, dan membandingkan nilai $t$ hitung dengan $t$ tabel. Adapun hipotesis yang ditetapkan yaitu:

1. $\mathrm{Ha}=$ budaya oraganisasi berpengaruh terhadap kinerja karyawan PT. Surabaya Panel Lestari.

2. Ho = budaya organisasi tidak berpengaruh terhadap kinerja karyawan PT. Surabaya Panel Lestari.

Pengolahan data dengan menggunakan SPSS, diperoleh nilai $\mathrm{t}$ hitung sebesar -1,513 dan nilai t tabel dengan taraf signifikansi 5\% (dua sisi) sebesar 2,002. Selanjutnya nilai $t$ hitung dan $t$ tabel dibandingkan, dengan ketentuan:

1. Jika $t_{\text {hitung }}>t_{\text {tabel}}$, maka Ho ditolak dan Ha diterima.

2. Jika $t_{\text {hitung }}<t_{\text {tabel }}$, maka Ho diterima dan Ha ditolak

Berdasarkan hasil perhitungan, nilai $t_{\text {hitung }}$ sebesar $-1,513<$ nilai $t_{\text {tabel }}$ sebesar 2,002, maka Ho diterima dan Ha ditolak. Dapat disimpulkan, bahwa budaya oraganisasi tidak berpengaruh signifikan terhadap kinerja karyawan.

\section{Lingkunga kerja (X2) Terhadap kinerja (Y)}

Untuk melihat pengaruh parsial antara lingkungan kerja terhadap kinerja karyawan, peneliti menggunakan tahap berupa penetapan hipotesis, pengolahan data kuantitatif dengan SPSS, dan membandingkan nilai $\mathrm{t}$ hitung dengan $t$ tabel. Adapun hipotesis yang ditetapkan yaitu:

1. Ha = lingkungan kerja berpengaruh terhadap kinerja karyawan PT. Surabaya Panel Lestari.

2. $\mathrm{Ho}=$ lingkungan kerja tidak berpengaruh terhadap kinerja karyawan PT. Surabaya Panel Lestari. 
Pengolahan data dengan menggunakan SPSS, diperoleh nilai $\mathrm{t}$ hitung sebesar 3,636 dan nilai t tabel dengan taraf signifikansi 5\% (dua sisi) sebesar 2,002. Selanjutnya nilai $t$ hitung dan $t$ tabel dibandingkan, dengan ketentuan:

1. Jika $t_{\text {hitung }}>\mathrm{t}_{\text {tabel}}$, maka Ho ditolak dan Ha diterima.

2. Jika $t_{\text {hitung }}<t_{\text {tabel }}$, maka Ho diterima dan Ha ditolak

Berdasarkan hasil perhitungan, nilai $t_{\text {hitung }}$ sebesar $3,636>$ nilai $t_{\text {tabel }}$ sebesar 2,002, maka Ho ditolak dan Ha diterima. Dapat disimpulkan, bahwa lingkungan kerja berpengaruh signifikan terhadap kinerja karyawan.

\section{Kompensasi finansial Terhadap Kinerja (Y)}

(X3)

Untuk melihat pengaruh parsial antara kompensasi finansial terhadap kinerja karyawan, peneliti menggunakan tahap berupa penetapan hipotesis, pengolahan data kuantitatif dengan SPSS, dan membandingkan nilai $\mathrm{t}$ hitung dengan $t$ tabel. Adapun hipotesis yang ditetapkan yaitu:

1. $\mathrm{Ha}=$ kompensasi finansial berpengaruh terhadap kinerja karyawan PT. Surabaya Panel Lestari.

2. Ho = kompensasi finansial tidak berpengaruh terhadap kinerja karyawan PT. Surabaya Panel Lestari..

Pengolahan data dengan menggunakan SPSS, diperoleh nilai $\mathrm{t}$ hitung sebesar 2,017 dan nilai t tabel dengan taraf signifikansi 5\% (dua sisi) sebesar 2,002. Selanjutnya nilai $t$ hitung dan $\mathrm{t}$ tabel dibandingkan, dengan ketentuan:

1. Jika $t_{\text {hitung }}>t_{\text {tabel }}$, maka Ho ditolak dan Ha diterima

2. Jika $t_{\text {hitung }}<\mathrm{t}_{\text {tabe }} \mathrm{l}$, maka Ho diterima dan Ha ditolak
Berdasarkan hasil perhitungan, nilai $t_{\text {hitung }}$ sebesar 2,017 nilai $t_{\text {tabel }}$ sebesar 2,002, maka Ho ditolak dan Ha diterima. Dapat disimpulkan, bahwa kompensasi finansial berpengaruh signifikan terhadap kinerja karyawan.

\section{Kompensasi Non finansial (X4) Terhadap Kinerja (Y)}

Untuk melihat pengaruh parsial antara kompensasi non finansial terhadap kinerja karyawan, peneliti menggunakan tahap berupa penetapan hipotesis, pengolahan data kuantitatif dengan SPSS, dan membandingkan nilai $t$ hitung dengan $t$ tabel. Adapun hipotesis yang ditetapkan yaitu:

1. $\mathrm{Ha}=$ kompensasi non finansial berpengaruh terhadap kinerja karyawan PT. Surabaya Panel Lestari.

2. Ho = kompensasi non finansial tidak berpengaruh terhadap kinerja karyawan PT. Surabaya Panel Lestari..

Pengolahan data dengan menggunakan SPSS, diperoleh nilai $t$ hitung sebesar 7,820 dan nilai $t$ tabel dengan taraf signifikansi 5\% (dua sisi) sebesar 2,002. Selanjutnya nilai $t$ hitung dan $t$ tabel dibandingkan, dengan ketentuan:

1. Jika $t_{\text {thitung }}>t_{\text {tabel}}$, maka Ho ditolak dan Ha diterima.

2. Jika $t_{\text {hitung }}<t_{\text {tabel }}$, maka Ho diterima dan Ha ditolak

Berdasarkan hasil perhitungan, nilai $t_{\text {hitung }}$ sebesar 7,820 nilai $t_{\text {tabel }}$ sebesar 2,002, maka Ho ditolak dan Ha diterima. Dapat disimpulkan, bahwa kompensasi non finansial berpengaruh signifikan terhadap kinerja karyawan. 
KESIMPULAN

\section{REKOMENDASI}

\section{Kesimpulan}

Setelah dilakukan pengujian keseluruhan hipotesis yang diajukan dalam penelitian ini, maka dapat diambil kesimpulan dari hipotesishipotesis tersebut, yaitu:

1. Budaya Organisasi tidak berpengaruh terhadap variabel kinerja karyawan PT. Surabaya Panel Lestari.

2. Lingkungan kerja berpengaruh signifikan terhadap variabel kinerja karyawan PT. Surabaya Panel Lestari.

3. Kompensasi finansial berpengaruh signifikan terhadap variabel kinerja karyawan PT. Surabaya Panel Lestari.

4. Kompensasi non finansial berpengaruh signifikan terhadap variabel kinerja karyawan PT. Surabaya Panel Lestari.

5. Budaya organisasi, lingkungan kerja, kompensasi finansial dan kompensasi non finansial berpengaruh secara simultan terhadap variabel kinerja karyawan PT. Surabaya Panel Lestari.

\section{Rekomendasi}

Berdasarkan pada hasil penelitian dan hasil perhitungan yang diperoleh maka dapat disimpulkan :

1. Untuk budaya kerja, lingkungan kerja, dan kompensasi finansial tetap harus dipertahankan dan ditingkatkan agar kinerja karyawan bisa meningkat secara maksimal.

2. Pihak manajemen diharapkan bisa memotivasi karyawan lewat kompensasi non finansial dengan cara memberikan tempat kerja yang nyaman, dan memberikan pujian dan penghargaan jika telah melakukan pekerjaan dengan baik atau mencapai target yang telah ditentukan, guna meningkatkan kinerja karyawan.

Bagi peneliti selanjutnya hasil penelitian ini dapat digunakan sebagai referensi atau pendukung bagi peneliti selanjutnya yang akan mengambil tema yang sama, peneliti merekomendasikan memperbanyak jumlah variabel-variabelnya yang dapat mempengaruhi kinerja dan menggunakan pendekatan dan analisis yang berbeda untuk mengetahui perbedaan analisis satu dengan analisis yang lainya.

\section{DAFTAR PUSTAKA}

Deal, T. E., and Kennedy, A.A.2007.Corporate

Culture:The rites and rituals of corporate life. Massachusetts: Addison-Wesley.

Gibson. 2008. Manajemen Sumber Daya Manusia, Edisi Keempat, Erlangga, Jakarta

Gogy Bara Kharisma2013 "Pengaruh Budaya Organisasi dan Lingkungan Kerja Terhadap Kinerja Karyawan Koperasi Serba Usaha Setya Usaha Di Kabupaten Jepara" Jurusan Manajemen Fakultas Ekonomi Universitas Negeri Semarang.

Hasibuan, Malayu S. P.2008. Manajemen Sumber Daya Manusia, Jakarta: PT.Bumi Aksara.

Mangkunegara, Anwar, Prabu. 2009. Manajemen Sumber Daya Manusia Perusahaan. Bandung : PT Remaja Rosdakarya. 
Mondy, R Wayne, 2008. Manajemen Sumber Daya Manusia, Jilid 1 Edisi sepuluh,Erlangga, Jakarta.

Nasution dan Rodiah.2008."Analisis Hubungan antara lingkungan dengan kepuasan Kerja Dosen FE Universitas Tarumanegara Jakarta".Jurnal Manajemen. 01,59-69.

Rivai, Veithzal, 2009. Manajemen Sumber Daya Manusia untuk Perusahaan, dari Teori ke Praktik, PT. Raja Grafindo Persada, Jakarta.

Robbins, Stephen. P. 2009. Perilaku Organisasi (alih bahasa Drs. Benjamin Molan), Edisi Bahasa Indonesia, Klaten: PT Intan Sejati.

Simamora, Henry. 2007. Manajemen Sumber Daya Manusia. STIE YKPN. Yogyakarta 